\title{
The House of Federation to Approve an Emergency Regime in Ethiopia: Peeking through the Preamble
}

\author{
Shimeles Ashagre \\ School of Law, Hawassa University, Hawassa, Ethiopia \\ Email: ashimeles@gmail.com
}

How to cite this paper: Ashagre, S. (2017). The House of Federation to Approve an Emergency Regime in Ethiopia: Peeking through the Preamble. Beijing Law Review, 8, 271-286.

https://doi.org/10.4236/blr.2017.83016

Received: June 16, 2017

Accepted: August 12, 2017

Published: August 15, 2017

Copyright $\odot 2017$ by author and Scientific Research Publishing Inc. This work is licensed under the Creative Commons Attribution International License (CC BY 4.0).

http://creativecommons.org/licenses/by/4.0/

\begin{abstract}
The charismatic leadership of Emperor Menelik has not only earned Ethiopia numerous nations, nationalities and peoples but also convinced the European colonialists to recognize the boundaries and existence of Ethiopia as a sovereign state. Following the glorious years of Emperor Menelik, bounded by political intrigues around the throne, deftly organized hectic negotiations to firmly land Ethiopia in the international political and legal space, and solidifying the accomplishment of Menelikian expansionism, Teferi Mekonnen was finally crowned the Emperor of Ethiopia in 1930. Questioning the existing political status of nations, nationalities and peoples came into the forefront during the reign of Haile Selassie although doomed to failure. The military government that assumed power in the footsteps of Haile Selassie was unsuccessful in the attainment of the request of ethno-nationalist political entrepreneurs who at the end brought down the government. The Federal constitution, in addition to making the right of the nations, nationalities and peoples' non-derogable, has established the House of Federation to be composed of representatives of nations, nationalities and peoples. Above all, sovereignty is vested in the nations, nationalities, and peoples. Conversant to any imagination, the House that represents these groups is denied the authority to decide on issues of public emergency-a situation that threatens the life of the State. In consequence, this paper argues that power should be returned to the legitimate holders-the nations, nationalities, and peoples-a power to be exercised by the House of the Federation.
\end{abstract}

\section{Keywords}

Menelik, State of Emergency, Nations, Nationalities and Peoples, The Federal Constitution, House of Federation 


\section{Introduction}

With more than eighty nations, nationalities and peoples, Ethiopia has the experience of concocting new cocktails of politics commencing with the reign of Emperor Menelik. With his charismatic leadership, Emperor Menelik has not only expanded the territorial span of Ethiopia but also convinced, by military might and tactical diplomacy, the then European colonialists to recognize the boundaries and existence of Ethiopia as a sovereign state. Following the glorious years of Emperor Menelik, Ethiopia's fate was foreshadowed until after the coronation of Emperor Haile Selassie in 1930. With his majestic years of rule over Ethiopia, Haile Selassie introduced a culture of written constitution, although unsuccessfully betted for reverting the stand of European colonialists on the Italian Fascists, and successfully pursued the unification, centralization and modernization attempts of Emperor Menelik. His neglect for the accommodation and recognition of nations, nationalities and peoples of "greater Ethiopia", coupled with political scandals, shortened his long years of reign and as the Ethiopians say goes: "buried in his hand-maden tunnel" (Zewde, 1995: pp. 99-114).

Following the humiliating fall of the imperial regime in 1974, socialism has made its way through the provisional military administration that hegemonically ruled the country for 17 years. The neglect the previous regimes showed to nations, nationalities and peoples seemed to have been shattered by the National Democratic Programme of 1976 that promised the recognition and respect of the right of nations, nationalities and peoples to self-determination (Brüne, 1990: pp. 189-199; Eshete, 1997: pp. 1-27). To the dismay of the cultural elitists and ethnic-oriented political entrepreneurs, Ethiopia of the 1970s and 1980s fell to the authoritarian and unaccommodating military rule that fomented bloody war between ethno-nationalist political parties and the military government. The fall of the socialist government was heralded in May 1991; the ethno-nationalists devoured the short-lived Constitution of the Peoples' Democratic Republic of Ethiopia.

With an unusual foundational philosophy of the respect and guarantee of the right of self-determination including secession to the nations, nationalities and peoples, the Ethiopian Peoples' Revolutionary Democratic Front held the scepter tightly and introduced the fourth written Constitution for Ethiopia-The Federal Constitution of Ethiopia. As opposed to the previous constitutions, sovereignty is vested in the nations, nationalities and peoples of Ethiopia and a parliamentary representation is made available by the erection of the House of Federation.

This article is a modest attempt to analyze the legal and political authority of the House of Federation with particular emphasis on the emergency regime of the current constitution. To this end, the next section will provide a short account of the background of Ethiopia since the reign of Emperor Menelik. An attempt will be made to debunk the position held by nations, nationalities and 
peoples of Ethiopia in the different political regimes it has passed through. The third section will analyze the constitutional precepts underlying state of emergency. We will evaluate the place given for the rights of nations, nationalities and peoples in emergency regimes. The fourth section will question the disempowering tendency of the constitution on the House of Federation by denying it to participate in the declaration of emergency regime. In this relation, a holistic reading of the constitution deflects the supreme authority given to the House of Peoples' Representatives. Section five will offer short conclusion.

\section{Background about Ethiopia}

Ethiopia began its large-scale expansion in the east and south in 1886 and 1887 by subjugating Harar Province (Keefer, 1973: p. 470). The current size "comprising the highlands, the key river systems, and a borderland buffer zone in low-lying, arid, or tropical zones" (Marcus, 1994: p. 105) was held between the sign-post of African independence-the battle of Adwa of 1896 (Milkias, 2005: p. 37) and the tripartite treaty between Britain, France and Italy of 1906. Paulos, in his usual elegance, claimed that "the battle of Adwa is rightfully considered one of the most important events in history, not because finer battles have not been fought or greater heroism displayed, but rather because it [is] the first major reversal for the European colonialists who, without consulting the people of Africa, were carving up the continent for themselves. Its cardinal import, however, lies in the fact that it is a victory for the underdog, a victory for right over wrong" (Ibid). Menelik's self-evident tactical superiority over Britain, France and Italy while negotiating and concluding agreements of border demarcation following the battle of Adwa earned Ethiopia a good deal of territory. That is why "emperor Menelik must be considered to be the father of modern Ethiopia" (Haile, 1986: p. 469; Marcus, 1963: pp. 81-94; Marcus, 1966: pp. 117-122; Sanderson, 1962: pp. 69-90; Sanderson, 1964: pp. 87-97; Giglio, 1965: pp. 221-231; Keefer, 1973: pp. 468-474; Novati, 1994: pp. 369-385; Rubenson, 1966: pp. 445-457; and Rubenson, 1964: pp. 243-283) as Bismarck had been to the German or Mazini and Garibaldi had been for Italy. The decease of Menelik in 1913, however, ushered in a political environment that can be characterized as a Hartian power interregnum.

In the intervening time, however, bounded by political intrigues around the throne, deftly organized hectic negotiations to firmly land Ethiopia in the international political and legal space, and solidifying the accomplishment of Menelikian expansionism, Teferi Mekonnen was finally crowned the Emperor of Ethiopia in 1930 assuming his coronation name Haile Sellassie. Holding the scepter firmly and giving such a hold constitutional base in 1931, Haile Sellassie experienced the janus-faced world politics as envisaged in the stand of Britain on the belligerence of Italy between 1935 and 1941. In his uninterrupted thirty-four majestic years of reign since the crush of the Italian invading military force, Haile Sellassie depended on "overt military power for authority and on the aris- 
tocracy and oligarchy for administrative support" (Herald G. Marcus, 1995: 173; Markakis, 1989: p. 119). Markakis argued that "in what became an absolute monarchy in fact as well as theory, political power was monopolized by the Emperor and was exercised at the centre through a coterie of handpicked retainers, while the Abyssinian aristocracy continued to rule the countryside, both north and south, where more than ninety per cent of the population lived". Meanwhile, a historic but failed attempt to depose Haile Sellassie was made in 1960 (Clapham, 1968: pp. 495-507) with the justification that "a self-perpetuating minority exploited Ethiopia's peoples and ... that the new leadership would work for progress and national unity" (Herald G. Marcus, 1995: 170). The ineptitude and the untimely "1688 Glorious Revolution" like-mindedness of the coup attempters, gave the Conquering Lion another chance. Following exoneration and execution, Haile-sellassie made new appointments that took "no notice of the forces that had shaped and inspired the recent crisis, and maintained his control over government" (Marcus, 1999: p. 20). Political reliability was his most important consideration, and the pattern of appointment was reminiscent of the way he had ordered government in prewar Ethiopia, when educated individuals had returned from schools abroad ready to work for the nation (Ibid., 22). It is clear, from the standpoint of the young educated, that it will take some years to quell the government of the emperor.

The 1960s witnessed the rise of radical students who "were obliged to confront the national issue and, after some agonizing life situation, opted for the Leninist principle of national self determination" (Markakis, 1989: p. 120). Entrapped with the Somalia project of winning back Ogaden, the ever-increasing demand of Eritrean dissidents for independence, the overwhelmingly escalating demand for land to the legitimate tillers and the suffering of millions by famine finally set a deadlock for the personal and despotic rule of Haile Sellassie in 1974.

The decimation of the imperial regime of Haile-sellasie "by a social revolution which erupted like a volcano avalanche rolling down a steep hill and spreading in all directions with increasing speed and might, (Tuso, 1997: p. 345), brought to power "a group of low-ranking military officers" (Haile, 2005: p. 1) under the name, Provisional Military Administrative Council or Derg. The Derg began as a deliberative committee of young military officers and enlisted men numbering 120-three representatives from each of the 40 units of the army and police (Keller, 1981: p. 328). Since February 1974, the Council has dissolved the monarchy, arrested several hundred notables of the old regime-executing some of them, promulgated far-reaching urban and rural and reform programs, and mobilized over 40,000 students and teachers to explain and help implement the revolutionary programs at the grass roots, particularly in the countryside" (Harbeson, 1977: pp. 217-218).

Conscious of the need to address the national question, the Derg instituted several policies providing for more freedom and fuller integration of subordinate ethnic groups (Keller, 1981: p. 330). Peculiarly, one of the power contenders of 
that time, the All-Ethiopian Socialist Movement (AESM), wholeheartedly "believed in self-determination within Ethiopia for minorities and nationalities". By using the opportunity of developing the 1976 National Democratic Revolution Programme, AESM introduced "nationalities' autonomy within a united Ethiopia” (Herald G. Marcus: 193). Article v, $\$ 1$ of the document provided that:

The right to self-determination of all nationalities will be recognized and duly respected ... No nationality will dominate another one since the history, culture, languages, and religion of each nationality will have equal recognition in accordance with the spirit of socialism. The unity of Ethiopia's nationalities will be based on the common struggle against feudalism, imperialism, bureaucratic capitalism and all reactionary forces. This united struggle is based on equality, brotherhood, and mutual respect. Given Ethiopia's existing situation, the problem of nationalities can be resolved if each nationality is accorded full rights of self-government (National Democratic Revolution Programme, as quoted in Yonatan Tesfaye Fessha, 2010: 172).

This recognition, ostensibly made to neutralize opposition and to cast the regime as progressive and fundamentally different from its predecessors, opened the door for cultural elites, or "political entrepreneurs" (Bariagaber, 2003: p. 224). Disappointed with the centralizing, authoritarian and unaccommodating tendency of the regime (Id., 225), the cultural elitists or the political entrepreneurs onsetted an obdurate predicament to the Ethiopian military cabal by exploiting the ever-escalating "ethnic conscious [ness] in the seventies and eighties" (Herald G. Marcus, 1995: 219). For instance, "the Tigray People's Liberation Front (TPLF), at its inception, was grounded in an ethno-nationalist consciousness generated by the cumulative grievances of Tigrayans against successive central governments of Ethiopia" (Berhe, 2004: p. 569). Similarly, as Semahagn noted, "the [sluggish and inadequate] measures undertaken by the military regime to respond to the political demands in addressing cultural and language rights ... [pushed] Eritrean People's Liberation Front (EPLF), Tigrayan People's Liberation Front (TPLF) and Oromo Liberation Front (OLF) [to onset] armed struggle ... against the regime" (Abebe, 2014: p. 72). On the whole, the Ethiopian Peoples' Revolutionary Democratic Front (EPRDF), a composite ethno-nationalist insurgents, spearheaded the move to bring down the Derg regime "like a powder house" (Tuso, 1997: p. 346) on May 28 1991. The demise of this regime marked the end of the system of centralized, authoritarian rule that characterized the political development of the Ethiopian state during this century (Paul, 1994: pp. 235-238).

The founders of a political regime may publicly proclaim what they take to be moral, metaphysical, or religious truths as the basis of that regime (Galston, 2005: p. 4). In this vein, the new leaders, along with the right of self-determination of all nations, nationalities or peoples of Ethiopia (The Transitional Period Charter, 1991: Art. 2), have aspired to remedy "past injustices by permitting the 
people of Ethiopia greater participation in national decision-making, while simultaneously preserving individual, group, and national identity" (McCracken, 2004: p. 183; The Federal Constitution of Ethiopia Proclamation, 1995: [hereinafter, the constitution], prmbl, para. 4). In fact, "the validity of this political move emanate from its attempts to remove the national oppression legacy of the country prior to 1991" (Kebede, 2013: p. 256; the Constitution: prmbl, para. 7). In essence, The recognition of the individual in its own capacity, nations, nationalities and peoples as forming a distinct group, and Ethiopia as a composite and unifying polity throughout the preamble of the Constitution instantiate the determination of the new leaders to take forward individualism, communitarianism and nationalism together.

On the basis of the foregoing background, we will detail the verisimilitude power-scepter-holding status of nations, nationalities and peoples of Ethiopia in the Federal Constitution. This analysis will heavily depend on the emergency clause of the Constitution.

\section{The Emergency Clause under the Constitution}

No state can sustain a free social space if its very existence is jeopardized by internal or external threats, and within limits it may do what is necessary to defend itself against destruction, even if measures clearly essential to self-defense restrict valuable liberties of individuals and groups (Galston, 2005: p. 3). Particularly, "unstable or young democracies tend repeatedly to resort to emergency powers, often as a way to protect or prolong the incumbent government against political opponents" (Ferejohn and Pasquino, 2006: p. 340). Ethiopia is "lucky enough never to face a circumstance that was so threatening as to justify or even require the use of emergency powers" before the currently existing one. However, a state of emergency declaration looking Television address of late Prime Minister Meles Zenawi Asres is an indelible exercise of constitutional authority in the history of Ethiopia. His prediction of a possible breakdown of law following the 2005 popular election forced him to ban the constitutional right of assembly for a month.

The emergency powers clause of the constitution is fraught with difficulties that warrant a visit: first, the catalogue of rights under the naming "political and democratic rights" (The Constitution: Art. 93(4)(B)). The minimal number of the rights that fall under the naming indicates something quixotic: the nomenclature of the state, the rights against torture, inhumane treatment, etc, the right to equality and the rights of nations, nationalities and peoples to self-determination up to secession and their rights to language. Particularly, the constitution has left out the right to life from the category of rights that deserve protection from suspension. More importantly, the constitution, while suspending the right to self-government, upholds the self-determination: how can a nation whose right of self-rule suspended exercise the right of self-determination?

One of the issues that accompany the declaration of emergency is the suspen- 
sion of human rights.

With respect to the suspension of human rights, constitutional arrangements may adopt any one of the following four approaches:

1) Enlisting those rights and freedoms that may be suspended during a declared state of emergency (a positive list approach),

2) Enumerating those rights and freedoms that may not be restricted or in any way violated even in times of acute exigency (a negative list approach);

3) A mixed approach, using a negative list ... And a positive list; And

4) Some constitutional arrangements make explicit reference to international instruments such as the major human rights conventions (Gross and Aolain, 2006: $35 \mathrm{ff})$.

Ethiopia falls into the category of constitutional arrangements that have adopted the negative listing approach. In view is the empowerment of the "the Council of Ministers to suspend ... political and democratic rights ... to the extent necessary to avert the conditions that required the declaration of a state of emergency" (The Constitution: Art. 93(4)(B)). The Council can not, however, suspend or limit the rights provided for in Articles 1, 18, 25, and sub-Articles 1 and 2 of Article 39 of this Constitution (Id., Art. 93(4)(C)).

The constitution falls short of meeting the dictum of the International Covenant on Civil and Political Rights with respect to the rights that form part of the non-derogable rights (The International Covenant on Civil and Political Rights, 1966: Art. 4(2)). For instance, while the Covenant makes the right to life (Article 6 ), the prohibition against the retroactive operation of the criminal law (Article 15), the right to recognition of legal personality (Article 16), the freedom of thought, conscience and religion (Article 18), and the prohibition of imprisonment for breach of contractual obligation (Article 11) nonderogable, they could not acquire the status of nonderogability in the Ethiopian Constitution. Nonetheless, article 18 of the Constitution, under the heading, [p] rohibition against Inhuman Treatment has put together the rights under arts. 7 and 8 of the Covenant. It is, however, important, to note that the above provision does not give recognition to the right of everyone not to "be subjected without his free consent to medical or scientific experimentation". By the same token, the Constitution, under the same provision, failed to contain the word "torture".

Taken together, the Constitution, by protecting the rights of everyone against cruel, inhuman and degrading treatment or punishment, slavery and servitude, is compatible with the dictum of the Covenant. With respect to its failing, on the one hand, no provision under chapter three provides for the prohibition of imprisonment for breach of contractual obligation; on the other hand, although the Constitution gives due recognition to the right to life (Art. 15), the prohibition against the retroactive operation of the criminal law (Art. 22) the right to recognition everywhere as a person (Art. 24(3)) and the Freedom of Religion, Belief and Opinion (Art. 27), it failed to include them in to the group of rights that should not be suspended during the time of state of emergency. 
In stark difference with the Covenant, the Constitution has made the nomenclature of the country (Art. 1), the right to equality before the law and equal protection of the law (Art. 25) and the right of nations, nationalities or peoples (Art. 39) nonderogable.

To start with, the nomenclature of the country "the Federal Democratic Republic of Ethiopia" (The constitution: Article 1 cum Art. 93(4)(c)) is guaranteed the position of a political right. This writer could trace no constitution that boldly states its nomenclature a political right. Hence, the Ethiopian Constitution is unique in this regard. The uniqueness of this Constitution is not only limited to giving it a sense of political right but also the executive, during the currency of state of emergency, cannot suspend the nomenclature "the Federal Democratic Republic of Ethiopia”.

The 1995 Constitution made the nations, nationalities and peoples the foundation of the territorial organization of Ethiopia. In effect, they "are given the right to internal self-determination within a federal structure" (Abdullahi, 1998: p. 444). More specifically, the member states of the federal democratic republic of Ethiopia are the reflections of the ethnic-orientation of the drafters: the belief in the foundational position of nations, nationalities and peoples. Accordingly arts. 46 and 47 provide for the establishment of member states around the foundational groups. Hence, all of the regional states are the composites of nations, nationalities and peoples. This organizational theme will only be realized in a federal form of structuration. Consequently, the non-derogable status of Article 1 can be justified by taking into account the impact it will have on the existence of the state as it is. The sole justification is the structuration: the drafters by giving the nomenclature the status of a political right, seemed to give robust protection to federalism that meaningfully accommodates the internal autonomy of nations, nationalities and peoples, a direct manifestation of Art. 39, 46 and 47 of the constitution.

The other uniqueness of the Ethiopian Constitution stems from its declaration of the rights of nations, nationalities and peoples as a typical subject of declaration of emergency. The conjoint reading of Art. 93(4)(C) and 93(4)(B) explicates that the Council of Ministers cannot suspend the rights of nations, nationalities and peoples to "an unconditional right to self-determination, including the right to secession" (The Constitution: Art. 39(1) and "the right to speak, to write and to develop its own language; to express, to develop and to promote its culture; and to preserve its history" (Id.: Art. 39(2)).

First, the inclusion of the rights of nations, nationalities or peoples to self-determination, language, culture and history within non-derogable political and democratic rights flows from the determination of the drafters of the Constitution to make "nations, nationalities and peoples" "pluralism.s second-order norms [that] determine the constitutional framework, provide a substantive normative criterion for assessing or designing a working constitutional order, and circumscribe the normative space for constitutional politics" (Rosenfeld, 2010: p. 247). This assertion emanates from two standpoints: first, the preamble, 
the philosophical statement of the Constitution, commences with the avowal of not the "we, the people of Ethiopia" but "we, the nations, nationalities and peoples of Ethiopia" thereby anchoring the constitutional politics of the country on the groups rather than individuals. Second, sovereignty, one of the fundamental principles of the Constitution (The Constitution: Art. 8), "resides in the Nations, Nationalities and Peoples of Ethiopia". Thus, the nations, nationalities and peoples are the holders of sovereignty, a concept more generally understood as an "institution which necessarily incorporates the relevant elements of the normative framework that shapes state building" (Zaum, 2007: p. 27) and hence "the ultimate source of authority" (Francis H. Hinsley, quoted in Zaum, 2007: p. 27). In effect, the nations, nationalities and peoples of Ethiopia are the ultimate source of authority.

Paradoxically, Article 39(3) of the Constitution that guarantees "every nation, nationality or people the right to a full measure of self-government which includes the right to establish institutions of government in the territory that it inhabits and to equitable representation in state and Federal governments" falls among the political and democratic rights the executive can suspend in the wake of state of emergency. The paradox is, how can a nation, nationality or people, whose right to a full measure of self-government is suspended, can exercise the right of self-determination including secession? It is important to bear in ones mind that "the right to self-determination, including secession, of every Nation, Nationality and People shall come into effect, [inter alia], [w] hen a demand for secession has been approved by a two-thirds majority of the members of the Legislative Council of the Nation, Nationality or People concerned" (The Constitution: Art. 39(4)(a)). From this perspective, it can be safely argued that the suspension of the right to a self-government, as a final analysis, suspends the right of self-determination including secession. This assertion flows from the belief that the legislative councils of nations, nationalities or peoples will be divested of their authority to approve the demand for self-determination or secession. This, in turn, debilitates the constitutional position given to nations, nationalities or peoples.

\section{The House of Federation to Declare or Approve State of Emergency}

The principal question this section is meant to address is-who has the power to declare state of emergency in Ethiopia: the council of ministers or the House of Peoples' Representatives? To whom should the approval of the proclamation declaring state of emergency submitted: the House of Peoples' Representatives or the House of Federation? The response to the first question will supposedly emerge from the cumulative understanding of Arts. 55(8), 77(10) and 93. The second question requires a holistic reading of the constitution including the preamble and Arts. 8, 50, 54 and 61.

To begin with, depending on the arrangement of system of government 
(presidential, semi-presidential, parliamentary, monarchic) or the state structure (confederal, federal or unitary), the organs that take primacy in the initiation, execution and termination of emergency regime might be at variance. Professors Oren Gross and Fionnuala Ni Aolain assertively stated that the "constitutions of Latin and South American [and former Communist] countries tend to vest in the president the authority to declare a state of exception as this reflects the strong position traditionally enjoyed by the executive in those countries" (Gross and Aolain, 2006: pp. 55-56). However, the majority of modern constitutions divide "the authority to invoke an emergency regime [between] the executive and legislative branches of government" (Id.: 56). The drafters of the Federal Constitution of Ethiopia devised a constitutional structure that vests solely in the executive the initiation of the declaration of state of emergency. While providing as such, Art. 93(1)(a) reads as follows: the Council of Ministers shall have the power to decree a state of emergency, should an external invasion, a breakdown of law and order which endangers the Constitutional order and which cannot be controlled by the regular law enforcement agencies and personnel, a natural disaster, or an epidemic occur. By the same token, Article 77(10) of the Constitution vests in the Council of Ministers "the power to declare a state of emergency". The primacy given to the Council of Ministers is clearly shown under Art. 55(8) that contains the phrase ... "in conformity with Article 93". Consequently, although the phrase "...shall declare state of emergency..." seem to vest in the House of Peoples' Representatives the power of initiating declaration of state of emergency, its qualification by the terms "in conformity with Art. 93" make it clear that the sole primacy is given to executive branch of the government. In effect, the perusal of the power-conferring provisions of the Constitution divulges that the House of Peoples' Representatives, by its own initiative, cannot declare state of emergency. We have to accordingly note that the first limb of Art. 55(8), i.e., in conformity with Art. 93 shall declare state of emergency, adds no importance and hence superfluous.

The Federal Constitution requires the Council of Ministers to involve the House of Peoples' Representatives in the emergency regime subject to the state of the House (The Recess and Time-in-Session of the House of Peoples' Representatives Proclamation, 1996). For instance, if the state of emergency is declared when the House of Peoples' Representatives is in session, the decree shall be submitted to the House within forty-eight hours of its declaration as per Art. 93(2)(a). Hence, if the conditions that call for the declaration of emergency happen between the final week of Meskerem and the final week of Yekatit and the first week of Miazia and the final week of Sene, the Council of Ministers is required to submit the legislation for approval within fourty-eight hours. According to Art. 93(2)(b), if the Council of Ministers decrees the emergency regime when the House of Peoples' Representatives is in recess, the Proclamation must be submitted to the House within fifteen days of its adoption. Hence, if the conditions that call for an emergency regime occur in Megabit or Hamle 1 to the fi- 
nal weeks of Meskerem, the Council is duty bound to submit the Proclamation within the fifteen days period.

Following the submission of the legislation, the House of Peoples' Representatives "shall consider and resolve on [the] decree of a state of emergency declared by the executive" (The Constitution: Art. 55(8)). Thus, the House of Peoples' Representatives partakes in the emergency regime by an ex post ratification of the proclamation. According to Art. 93(2), the House of Peoples' Representatives can vote for or against the undertaking of the Council of Ministers. The question that this analysis begs is that won't the House of Peoples' Representatives decline approval and hence result in the immediate repeal of the legislation? Such results will be unlikely in countries of the like of Ethiopia whose parliament is controlled by one party. It may even be argued that let alone a disapprobation by a one-party-parliament, "times of acute crises may ... lead the opposition to mute its criticisms of the government or even join the government itself as part of a coalition of national unity" (Gross and Aollian, 2006: p. 55).

The second question this section is meant to respond to is to whose approval the Council of Ministers should submit the law proclaiming state of emergency-the House of Peoples' Representatives or the House of Federation? As supposed above, the response to this query requires a holistic reading of the constitution starting with the preamble.

A thorough and careful study of the preamble in conjunction with the operative provisions of the Federal Constitution of Ethiopia implies that it should have been the House of Federation, rather than the House of Peoples' Representatives, that should be authorized to approve the proclamation of state of emergency.

It is unusual to browse and find written constitutions that lack Preamble (Ginsburg, Foti, \& Rockmore, 2013: p. 305; Roach, 2001: p. 129; Konig, 2009: p. 1296). Preambles to constitutions "are framed as the quintessential expression of national values (McKenna, Simpson, \& Williams, 2001: quoted in Ginsburg, Foti, \& Rockmore, 2013: FN4). Specifically, preambular statements "make vivid the complex relationship between the presumptive ends underlying a given constitution and the particular means that it authorizes to achieve those ends" (Levinson, 2012: p. 157). The preamble of the Federal Constitution of Ethiopia, with its two hundred and forty-nine words, does not only provide for the "presumptive ends" and the "particular means to achieve those ends" but also the existence of rich and proud cultural legacies, common interest and outlook that resulted from long and interactive life within the territory of Ethiopia (The Constitution: prmbl, Para. 3).

The presumptive ends of the Federal Constitution of Ethiopia are the following: 1) full and free exercise of the right to self-determination; 2) a sustainable and mutually supportive conditions for ensuring respect for rights and freedoms and for the collective promotion of interests; 3 ) consolidation of the peace and the prospect of a democratic order which the protracted struggles and sacrifices 
have brought about; and 4) a political community founded on the rule of law. The drafters of the Federal constitution of Ethiopia subjected the realization of these ends on the following means: a) full respect of individual and people's fundamental freedoms and rights; b) rectification of historically unjust relationships and by further promoting our shared interests; and c) living as one economic community.

Preambles often speak in the name of a distinct people, either real or fictional, who are both the creators and subjects of the constitutional order (McKenna et al., 2001). The creators and subjects of the Ethiopian constitutional order are "the Nations, Nationalities and Peoples of Ethiopia". Each of the ends referred to in the preamble are attributable to the nations, nationalities and peoples of Ethiopia as a whole. The founders of the new political order of Ethiopia manifestly indicated that it is the rights of the nations, nationalities and peoples that justify the "act of the foundation" of today's Ethiopia. A clear manifestation of this claim is the attribution of sovereignty to the nations, nationalities and peoples of Ethiopia (The constitution: Art. 8). Their sovereignty shall be expressed through their representatives elected in accordance with this Constitution and through their direct democratic participation (Id.: Art. 8(2)). As the occupants of sovereignty, the nations, nationalities and peoples of Ethiopia "are the ultimate and self-governing masters of the institutions of the state" (Veitch, Christodoulidis and Farmer, 2012: p. 15). As evinced beforehand, the nations, nationalities and peoples will exercise their legal and political authority through their representatives. According to Article 61(1) of the Constitution, it is via the House of the Federation, the second chamber of the parliament which is composed of representatives of Nations, Nationalities and Peoples, that they exercise their ultimate political and legal power. While legal power is "a kind of supreme normative power or highest possible legal authority" (Id.: p. 15), Political power is concerned with the state's or any agent's ability to get others act in ways that they desire even when the subject does not want to do what the agent wants him to do (Stanford Encyclopedia of Philosophy). On the whole, the holistic perusal of the Federal Constitution signifies the ultimacy of the House of Federation.

Conversant to the values and ends aspired by the preamble and the provisions dealing with sovereignty and representation, Article 50(3) of the Constitution vests the highest authority in the House of Peoples Representatives. In common parlance, the House of Peoples' Representatives act and speak on behalf of their electorate officially. Their representation is for the interests of individuals rather than that of a group such that they do not act and speak on behalf of nations, nationalities and peoples. It can be argued that the House of Peoples' Representatives is given supreme authority illegitimately. In consequence, we argue that the Council of Ministers, in instances that require the promulgation of state of emergency should submit the legislation to the House of Federation rather than the House of Peoples' Representatives for approval. This reasoning emanates from the basic consequence of state of emergency: its ability to threaten the life 
of the state, a composite of the nations, nationalities and peoples whose ultimate-power-occupancy is unswervedly contained in the Federal Constitution.

\section{Conclusion}

The last twenty-five years of Ethiopia's political order has passed within the tightening and loosening political domination of the Ethiopia Peoples' Revolutionary Democratic Front. As a political party born within a period of political turmoil that is characterized by ethnic-orientation and cultural-elitism, the Ethiopian People's Revolutionary Democratic Front was founded for and on the realization of the rights of nations, nationalities and peoples of Ethiopia. The nations, nationalities and peoples that presently excel eighty, unified into the Ethiopian polity at the end of the 19th century, with their distinct customary norms and cultural values, had been the subjects of oppression as is repeatedly claimed by the Party. That is why some writers claimed the dominant party has dropped the "land question" and took up the "nationality question" at its inception.

The Federal Constitution, heralded in 1994, gives unprecedented position to the fate of nations, nationalities and peoples. They were considered as the sole actors and subjects of this constitution. More importantly, they are the occupants of sovereignty and, hence, the ultimate authority of the nation. The direct expression of this, although paradoxical, is the non-derogability of the rights of nations, nationalities and peoples to self-determination up to secession. Given their constitutional position, the nations, nationalities and peoples, through the House of Federation, can interpret the constitution (The constitution: Art. $62(1))$. Although it is clearly provided in the constitution as to the non-derogability of the right to self-determination up to secession, the derogability of their right to self-rule has played down the guarantee. It is easy to observe that no nation which is divested of the right to self-rule can vote for self-determination or secession. Hence, their pedestal political position is put to a halt or at least compromised.

To the dismay of the nations, nationalities and peoples supreme legal and political authority as evidenced in the text of the constitution, the House of Peoples' Representatives is made the holder of supreme political authority in Federal government. By virtue of this political status, the House of Peoples' Representatives deliberate and decide on the approval or repeal of proclamations that declare state of emergency when submitted by the Council of Ministers. This power-conferring constitutional scheme negates the ends and values evinced in the preamble and the constitutional dictum contained in sovereignty and representation. Such a disempowerment subjects the verisimilitude supreme authority occupants to the decision of another political institution illegitimately. Although no one claimed for the reconsideration of the power-conferring provisions of the Federal Constitution to the present, it will be a hotly debatable issue in the near future. 


\section{Acknowledgements}

I would like to extend my heartfelt appreciation to the editorial staff of the BLR; the anonymous reviewers have extended their unreserved help to the enrichment of the paper; the errors left uncorrected remain my own; I should recognize the contributions of Andualem Nega, Filata Gigiso and Mesganaw Kefelew. You can contact me via my Email ashimeles@gmail.com.

\section{References}

Abdullahi, A. M. (1998). Article 39 of the Ethiopian Constitution on Secession and SelfDetermination: A Panacea to the Nationality Question in Africa. Verfassung und Recht in Übersee Law and Politics in Africa, Asia and Latin America, 31, 440-455. https://doi.org/10.5771/0506-7286-1998-4-440

Abebe, S. G. (2014). The Last Post-Cold War Socialist Federation: Ethnicity, Ideology and Democracy in Ethiopia. London: Ashgate Publishing.

Bariagaber, A. (2003). Ethnicity and Constitutionalism in Ethiopia. In C. E. Tofollo (Ed.), Emancipating Cultural Pluralism (pp. 221-237). Albany: State University of New York.

Berhe, A. (2004). The Origins of the Tigray People's Front. African Affairs, 103/413, 569592. https://doi.org/10.1093/afraf/adh024

Brüne, S. (1990). Ideology, Government and Development-The People's Democratic Republic of Ethiopia. Northeast African Studies, 12, 189-199.

Clapham, C. (1968). The Ethiopian Coup d'Etat of December 1960. The Journal of Modern African Studies, 6, 495-507. https://doi.org/10.1017/S0022278X00017730

Eshete, A. (1997). Ethiopia and the Bolshevik Revolution: 1917-1935. Africa: Rivista Trimestrale di Studi e Documentazione dell'Istituto Italiano perl'Africa e l'Oriente, 32, 127.

Ferejohn, J., \& Pasquino, P. (2006). Emergency Powers. In S. John, B. H. Dryzek, \& A. Phillips (Eds.), Oxford Handbook of Political Theory (pp. 333-348). Oxford: Oxford University Press.

Galston, W. A. (2005). The Practice of Liberal Pluralism. Cambridge: Cambridge University Press.

Giglio, C. (1965). Article 17 of the Treaty of Uccialli1. The Journal of African History, 6, 221-231. https://doi.org/10.1017/S0021853700005636

Ginsburg, T., Foti, N., \& Rockmore, D. (2013). 'We the Peoples': The Global Origins of Constitutional Preambles. George Washington International Law Review, 46, 305. https://doi.org/10.2139/ssrn.2360725

Gross, O., \& Aolain, F. N. (2006). Law in Times of Crisis: Emergency Powers in Theory and Practice. New York: Cambridge University Press. https://doi.org/10.1017/CBO9780511493997

Haile, G. (1986). The Unity and Territorial Integrity of Ethiopia. The Journal of Modern African Studies, 24, 465-487. https://doi.org/10.1017/S0022278X00007126

Haile, M. (2005). “Comparing Human Rights in Two Ethiopian Constitutions: The Emperor's and the "Republic's"-Cucullus non Facit Mona Chum". Cardozo Journal of International and Comparative Law, 13, 1-59.

Harbeson, J. W. (1977). Socialism, Traditions, and Revolutionary Politics in Contemporary Ethiopia. Canadian Journal of African Studies, 11, 217-218.

https://doi.org/10.2307/483622 
Kebede, G. (2013). Political Corruption: Political and Economic State Capture in Ethiopia. European Scientific Journal, 9, 250-278.

Keefer, E. C. (1973). Great Britain and Ethiopia, 1897-1910. Competition for Empire. The International Journal of African Historical Studies, 6, 468-474. https://doi.org/10.2307/216612

Keller, E. J. (1981). The Revolutionary Transformation of Ethiopia's Twentieth-Century Bureaucratic Empire. The Journal of Modern African Studies, 19, 307-335. https://doi.org/10.1017/S0022278X00016955

Konig, D. T. (2009). Why the Second Amendment Has a Preamble: Original Public Meaning and the Political Culture of Written Constitutions in Revolutionary America. UCLA Law Review, 56, 1295-1342.

Levinson, S. (2012). Do Constitutions Have a Point? Reflections on "Parchment Barriers" and Preambles”. In E. F. Paul, F. D. M. Jr, \& J. Paul (Eds.), What Should Constitutions Do (pp. 150-178)? Cambridge: Cambridge University Press.

Marcus, H. G. (1963). Ethio-British Negotiations Concerning the Western Border with Sudan, 1896-1902. The Journal of African History, 4, 81-94.

https://doi.org/10.1017/S0021853700003728

Marcus, H. G. (1966). The Foreign Policy of the Emperor Menelik 1896-1898 A Rejoinder. The Journal of African History, 7, 117-122. https://doi.org/10.1017/S0021853700006113

Marcus, H. G. (1994). A History of Ethiopia. London: University of California Press.

Marcus, H. G. (1999). 1960, the Year the Sky Began Falling on Haile Sellassie. Northeast African Studies (New Series), 6, 11-25. https://doi.org/10.1353/nas.2003.0004

Markakis, J. (1989). Nationalities and the State in Ethiopia. Third World Quarterly (Ethnicity in World Politics), 11, 118-130. https://doi.org/10.1080/01436598908420195

McCracken, M. J. (2004). Abusing Self-Determination and Democracy: How the TPLF Is Looting Ethiopia. Case Western Reserve Journal of International Law, 183-222.

McKenna, M., Simpson, A., \& Williams, G. (2001). "First Words: The Preamble to the Australian Constitution" Quoted in Tom Ginsburg, Nick Foti \& Daniel Rockmore (2013). 'We the Peoples': The Global Origins of Constitutional Preambles. The George Washington International Law Review, 46, 305-340.

Milkias, P. (2005). The Battle of Adwa: The Historic Victory of Ethiopia over European Colonialism. In P. Milkias, \& G. Metaferiya (Eds.), The Battle of Adwa: Reflections on Ethiopia's Historic Victory against European Colonialism (pp. 37-87). Baltimore, MA: Algora Publishing.

National Democratic Revolution Programme as Quoted in Fessha, Y. T. (2010). Ethnic Diversity and Federalism: Constitution Making in South Africa and Ethiopia. London: Ashgate.

Novati, G. C. (1994). Italy in the Triangle of the Horn. Too Many Corners for a Half Power. The Journal of Modern African Studies, 32, 369-385. https://doi.org/10.1017/S0022278X00015147

Paul, J. C. N. (1994). Human Rights and the Structure of Security Forces in Constitutional Orders: The Case of Ethiopia. William \& Mary Bill of Rights Journal, 3, 235-238.

Roach, K. (2001). The Uses and Audiences of Preambles in Legislation. Social Science Electronic Publishing, 47, 129-159.

Rosenfeld, M. (2010). Should Constitutional Democracies Redefine Emergencies and the Legal Regimes Suitable for Them? In A. Sarat (Ed.), Sovereignty, Emergency, Legality (pp. 240-272). New York: Cambridge University Press. 
https://doi.org/10.1017/CBO9780511711886.010

Rubenson, S. (1964). The Protectorate Paragraph of the Wichale Treaty. The Journal of African History, 5, 243-283. https://doi.org/10.1017/S0021853700004837

Rubenson, S. (1966). Professor Giglio, Antonelli and Article XVII of the Treaty of Wichale. The Journal of African History, 7, 445-457.

https://doi.org/10.1017/S0021853700006526

Sanderson, G. N. (1962). Contributions from African Sources to the History of European Competition in the Upper Value of the Nile1. The Journal of African History, 3, 69-90. https://doi.org/10.1017/S0021853700002747

Sanderson, G. N. (1964). The Foreign Policy of the Negus Menelik, 1896-1898. The Journal of African History, 5, 87-97. https://doi.org/10.1017/S0021853700004527

Stanford Encyclopedia of Philosophy. http://Plato.Stanford.edu/

The Federal Constitution of Ethiopia Proclamation, 1995.

The International Covenant on Civil and Political Rights (ICCPR), 1966.

The Recess and Time-in-Session of the House of Peoples' Representatives Proclamation, 1996.

The Transitional Period Charter of Ethiopia, 1991.

Tuso, H. (1997). Ethiopia: New Political Order. Ethnic Conflict in the Post Cold War Era. Africa Rivista Trimestrale di Studi e Documentazione dell'Istituto Italiano per l'africa e l'oriente, 52, 343-364.

Veitch, S., Christodoulidis, E., \& Farmer, L. (2012). Jurisprudence: Themes and Concepts. Abingdon: Routledge.

Zaum, D. (2007). The Sovereignty Paradox: The Norms and Politics of International State building. New York: Oxford University Press. https://doi.org/10.1093/acprof:oso/9780199207435.001.0001

Zewde, B. (1995). Hayla-Sellase: From Progressive to Reactionary. Northeast African Studies (New Series), 2, 99-114. https://doi.org/10.1353/nas.1995.0037

Submit or recommend next manuscript to SCIRP and we will provide best service for you:

Accepting pre-submission inquiries through Email, Facebook, LinkedIn, Twitter, etc. A wide selection of journals (inclusive of 9 subjects, more than 200 journals)

Providing 24-hour high-quality service

User-friendly online submission system

Fair and swift peer-review system

Efficient typesetting and proofreading procedure

Display of the result of downloads and visits, as well as the number of cited articles

Maximum dissemination of your research work

Submit your manuscript at: http://papersubmission.scirp.org/

Or contact blr@scirp.org 